\title{
First records of Sticta weigelii s.str. from Bolivia confirmed by molecular data
}

\author{
Emilia A. Ossowska \\ Department of Plant Taxonomy and Nature Conservation, Faculty of Biology, University of Gdansk, Wita Stwosza 59, \\ PL-80-308 Gdansk, Poland \\ E-mail: emilia.ossowska@ug.edu.pl \\ ORCID: 0000-0002-1357-6071
}

\begin{abstract}
The first records of Sticta weigelii s.str. from Bolivia confirmed by molecular data are presented. The species is characterized by the presence of marginal isidia, which are darker than the thallus, usually cylindrical (not flattened), thin, dark brown to black lower tomentum and often partly yellow cyphellae. Previously, the presence of $S$. weigelii in Bolivia was based only on a morphological concept, encompassing various unrelated species, whereas the occurrence of $S$. weigelii s.str. was uncertain.
\end{abstract}

Keywords: Ascomycota, Peltigeraceae, Lobarioideae, ITSrDNA, morphodemes

\section{INTRODUCTION}

The subcosmopolitan genus Sticta (Schreb.) Ach. occurs in humid, cool to warm-temperature environments with high precipitation or humidity (Galloway, 1994, 1997, 2007; Moncada, 2012; Moncada et al., 2014a, 2020; Suárez \& Lücking, 2013). It is characterized by foliose thalli with or without stipe, with different types of photobionts (green algae or/and cyanobacteria) and characteristic pores (cyphellae) on the lower surface. On the upper surface isidia, soredia, phyllidia or lobules may develop, with or without apothecia. Lobes are variously indented (Galloway, 1994, 1997, 2007; Moncada, 2012; Moncada \& Lücking, 2012; Moncada et al., 2014b). Until now, more than 200 species of Sticta have been described (Moncada \& Lücking, 2012; Moncada et al., 2013a, 2013b, 2020, 2021a, 2021b; Lücking et al., 2017; Mercado-Díaz et al., 2020), but according to Moncada et al. (2013b, 2021b) the number of species belonging to this genus is more than twice as high. The discrepancy between the described and the potential number of Sticta species is related to the fact that in many countries no detailed studies have been undertaken. For example, recent research conducted on Sticta in Puerto Rico revealed the presence of more than ten taxa potentially endemic to that island (Mercado-Diaz et al., 2020). Bolivia, conversely, is one of the relatively understudied countries in term of the presence of Sticta species.
The checklist of lichens from Bolivia (Rodriguez de Flakus et al., 2016) lists only 11 names under the genus Sticta, however, most of these reports are historical and require re-examination as in many cases very wide species delimitations were used: S. damicornis (Sw.) Ach. (a Caribbean endemic species), S. fuliginosa (Dicks.) Ach., S. isidiokunthii Moncada \& Lücking, S. kunthii Hook, S. laciniata (Sw.) Ach., S. sinuosa Pers., S. sinuosa var. macrophylla (Bab.) Müll. Arg. [三 Sticta macrophylla Bory ex Delise] (a paleotropical species), S. tomentosa (Sw.) Ach., S. tomentosa var. dilatata (Nyl.) Hue [” S. dilatata (Nyl.) Vain.], S. umbilicariiformis Hochst. ex Flot. (an African species) and S. weigelii (Ach.) Vain. (Nylander, 1859, 1861; Rusby, 1896; Herzog, 1922, 1923; Moncada \& Lücking, 2012; Moncada et al., 2018; Simon et al., 2018; Lücking et al., 2021). Furthermore, intensive lichenological studies conducted in Bolivia indicate that the number of lichen taxa exceeds 1400 (Rodriguez de Flakus et al., 2016; Guzow-Krzemińska et al., 2019). Therefore, it can be assumed that the number of Sticta species might also be much higher than previously known in Bolivia. In Colombia, for example, a country with a similar high biodiversity as Bolivia, about 150 Sticta taxa have been described, of which 100 were recognized as new to science (Moncada et al., 2012-2014).

One of the Sticta species reported from Bolivia is S. weigelii s.lat. (Herzog, 1922, 1923; Feuerer et al., 1998). It associates with cyanobacteria as photobionts. The lobes are elongated with the 
margins densely covered by dark, cylindrical isidia. The lower surface is dark reddish-brown with thin, dark tomentum and $\mathrm{K}+$ intensive yellow medulla with white to yellow cyphellae (Galloway, 1994, 2006; Moncada, 2012, Moncada et al., 2021a). It occurs in tropical climate regions in well-preserved forest (Mercado-Diaz et al., 2020; Moncada et al., 2021a).

This narrow circumscription corresponding to a phylogenetically redefined species (MercadoDíaz et al., 2020) is in contrary to a previous broad application of $S$. weigelii that included any material with cyanobacteria and marginal isidia. However, molecular results indicate that this broad morphological species concept is inappropriate, because it includes several phylogenetically distant taxa, which are overall similar but differ in various morphological details (McDonald et al., 2003; Moncada et al. 2014b, 2020, 2021a). Consequently, records of $S$. weigelii complex may refer to various species, including e.g., S. andina B. Moncada, Lücking \& Sérus., S. beauvoisii Del., S. carolinensis McDonald, S. scabrosa B. Moncada, Merc.-Díaz \& Bungartz, or S. tatamana Moncada \& Coca (McDonald et al., 2003; Moncada, 2012, Moncada et al., 2013b, 2014b; 2021a). Therefore, proper identification of $S$. weigelii s.str. should be supported by molecular analyses. In addition, the wide geographical distribution of this taxa should be treated as „possible” until confirmed by phylogenetic results (Moncada, 2012; Moncada et al., 2021a).

The main aim of study was to revise specimens belonging to Sticta weigelii complex from Bolivia. In this paper the first molecular evidence for the presence of $S$. weigelii s.str. in Bolivia is presented, based on the results of phylogenetic studies, supplemented by morphological and anatomical description of the taxon, its geographical distribution and ecological requirements together with the discussion on taxa belonging to the $S$. weigelii complex.

\section{MATERIALS AND METHODS}

\section{Taxon sampling}

Fresh material (in total ca. 200 specimens of Sticta) for this study was collected during fieldwork in Bolivia in 2010-2017 and is deposited in LPB and UGDA. In addition, ca. 100 specimens deposited in KRAM and LPB were reviewed. The morphology and anatomy were studied under the stereomicroscope and diagnostic features reported in previous literature references were examined. In addition, a spot test reaction in K (10-20\% potassium hydroxide solution) was performed (Orange et al., 2001).

A total of 60 isidiate Sticta specimens were used for morphological and chemical studies (data not shown), and only nine of these were consistent with the present circumscription of $S$. weigelii s.str.. Two fresh specimens were used for DNA extraction and phylogenetic analyses.

\section{DNA extraction, amplification and sequencing}

DNA was extracted using the Plant \& Fungi DNA Purification Kit (Eurx, Poland) according to the manufacturer's protocol. DNA extracts were amplified using the primers ITS1F and ITS 4A (White et al., 1990; Gardes \& Bruns, 1993). PCR reactions were performed with the following program: initial denaturation $94^{\circ} \mathrm{C}$ for $3 \mathrm{~min}$ and 33 cycles of $94^{\circ} \mathrm{C}$ for $30 \mathrm{sec}$; annealing at $52^{\circ} \mathrm{C}$ for $45 \mathrm{sec}$; extension at $72^{\circ} \mathrm{C}$ for $1 \mathrm{~min}$ and final extension at $72^{\circ} \mathrm{C}$ for $10 \mathrm{~min}$. The PCR products were cleaned using Wizard SV Gel and PCR Clean Up System (Promega, US) following the instructions of the manufacturer and sequenced using the Macrogen sequencing service (http://www.macrogen.com).

\section{Phylogenetic analyses}

The newly obtained sequences were compared with Sticta sequences deposited in GenBank using BLAST search (Altschul et al., 1997). The new sequences were automatically aligned together with selected representatives of the $S$. weigelii morphodeme in Seaview (Galtier et al., 1996; Gouy et al., 2010) using the algorithm Muscle (Edgar, 2004). The final alignment consisted of 31 ITSrDNA sequences and 568 characters. Twenty-nine sequences of Sticta were downloaded from GenBank. Sequence of Lobaria pulmonaria (L.) Hoffm. (AF129284) was used as outgroup.

The optimal DNA substitution model was determined using AIC (Akaike Information Criterion) within MrModeltest 2.0 (Nylander, 2004) for MrBayes settings. The GTR+I model was selected. Bayesian analyses (BI) were performed using MrBayes v. 3.2.2 (Huelsenbeck \& Ronquist, 
2001; Ronquist \& Huelsenbeck, 2003) on the CIPRES Science Gateway (Miller et al., 2010). Metropolis-coupled Markov chain Monte Carlo (MCMCMC) was used. Two parallel MCMCMC runs were performed, using four independent chains and 1 milion generations, sampling every 1000th tree. The initial 250 trees $(25 \%)$ were discarded as burn-in, and posterior probabilities were estimated by constructing a 50\% majority rule consensus tree of all sampled post burn-in trees. The Bayesian tree is presented in Fig. 1 with added posterior probabilities.

\section{RESULTS \& DISCUSSION}

Sequences of two specimens of $S$. weigelii s.str. (MZ292976 and MZ292977), as defined by Mercado-Diaz et al. (2020), were obtained from material collected in Bolivia. In the phylogenetic tree (Fig. 1), they clustered within the clade

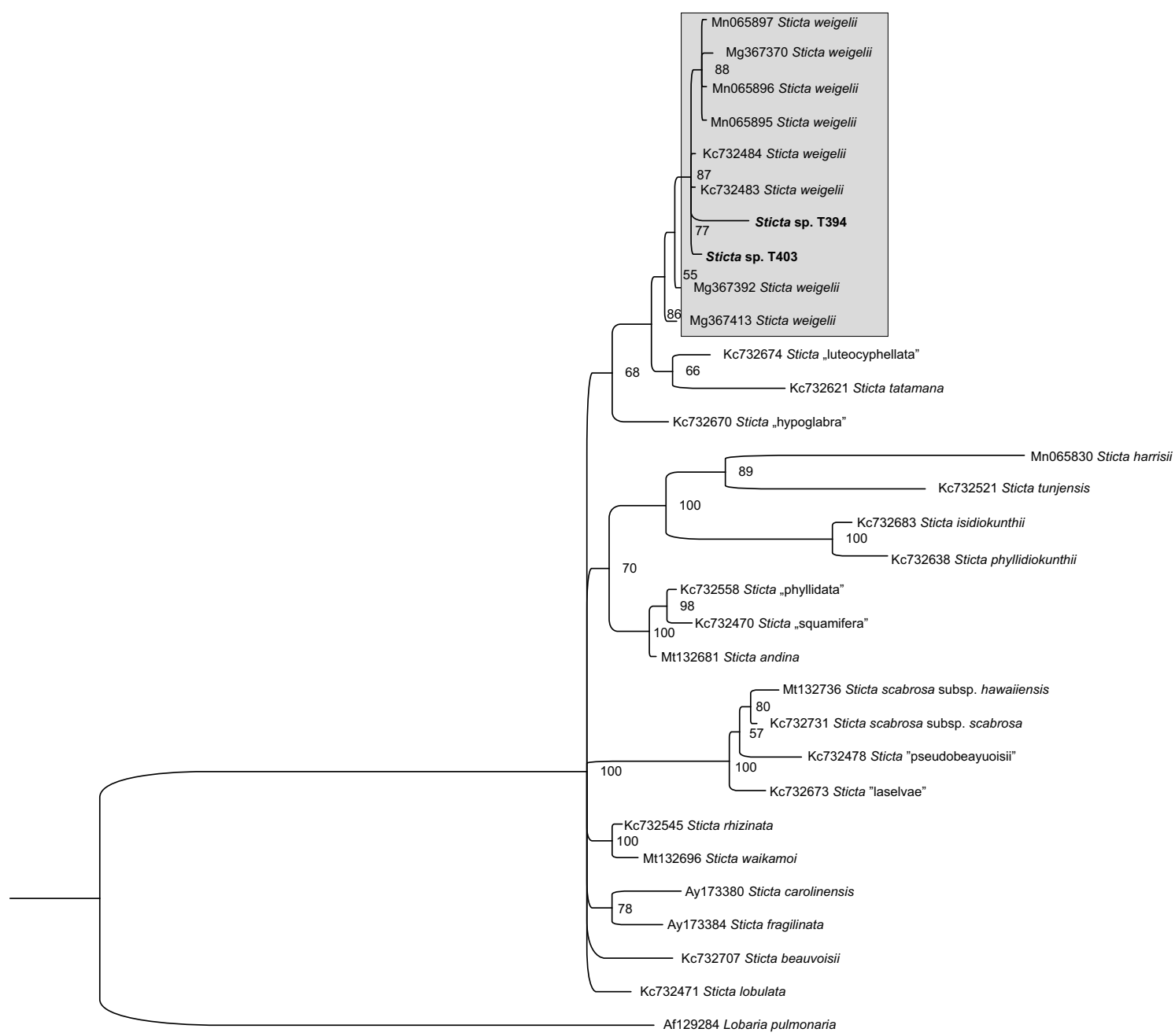

Fig. 1. Phylogenetic relationships of Sticta weigelii morphodem based on Bayesian analysis of nucITS rDNA dataset. Posterior probabilities values are shown near the internal branches. GenBank accession numbers of sequences downloaded from GenBank are listed on the tree with species names. Clade of $S$. weigelii is highlighted. Specimens newly sequenced for this study of S. weigelii are in bold. KC732471 Sticta sp. * undescribed species provincially called Sticta lobulata in Moncada (2012) and Moncada et al. $(2014,2020)$. 
corresponding to $S$. weigelii s.str. with sequences obtained by Moncada et al. (2014b), Widhelm et al. (2018) and Mercado-Díaz et al. (2020). These specimens are characterized by the presence of marginal, cylindrical isidia darker than the thallus, a thin, dark tomentum, white to yellow cyphellae, and $\mathrm{K}+$ intensive yellow medulla. Additional material was compared with these two specimens and it allowed determining further seven specimens of this taxon from the collection of Sticta specimens from Bolivia.

According to Moncada et al. (2014b, 2020, 2021a) the morphotype $S$. weigelii comprises species from the following clades (species with quotation marks - not yet formally described): S. weigelii (S. weigelii s.str., S. "luteocyphellata", S. tatamana), S. scabrosa (S. "laselvae", S. "pseudobeauvoisii", S. scabrosa B. Moncada, Merc.-Díaz \& Bungartz), S. kunthii (S. phyllidiokunthii B. Moncada \& Lücking, S. isidiokunthii); S. canariensis (S. carolinensis, S. fragilinata McDonald), S. fuliginosa (S. tunjensis Moncada \& Lücking, S. harrisii Merc.-Díaz, Moncada \& Lücking), S. andina (S. andina, S. "phyllidata", S. "squamifera"), S. beauvoisii, S. "hypoglabra",
Sticta sp. [an undescribed species provincially called Sticta "lobulata" in Moncada (2012) and Moncada et al. (2014b, 2020)], S. rhizinata B. Moncada \& Lücking and S. waikamoi B. Moncada $\&$ Lücking. The colour and thickness of the lower tomentum, the type and morphology of vegetative propagules, and the colour of the cyphellae, are features that distinguish these taxa from $S$. weigelii s.str. (Table 1), in addition to their ecology (McDonald et al., 2003; Moncada et al., 2014b, 2021a,b; Widhelm et al., 2018; Mercado-Díaz et al., 2020). Sticta andina, S. fragilinata, S. lasalvae, S. phyllidiokunthii, S. "pseudobeauvoisii" and S. scabrosa produce dorsiventral phyllidia (Moncada et al., 2013, 2014b, 2020, 2021a). Sticta "phyllidiata" and S. "squamifera" produce lobules instead of isidia (Moncada, 2012). Other taxa have isidia that are morphologically different from those present in S. weigelii s.str., e.g., in S. "hypoglabra" they are paler than the thallus (Moncada, 2012). The colour of the tomentum is also a distinguishing feature, e.g. in S. isidiokunthii it is beige vs. dark brown in S. weigelii s.str. (Moncada \& Lücking, 2012).

Table 1. Differences in type of vegetative propagules and their morphology as well as the colour of the tomentum between species of $S$. weigelii morphodeme

\begin{tabular}{|c|c|c|c|}
\hline Species & Vegetative propagules & Morphology of propagules & Tomentum \\
\hline S. harrisii & & & dark brown \\
\hline S. fragilinata & & & grey to brown \\
\hline S. laselvae & & narrow at the base and easily & grey to brown \\
\hline S. phyllidiokunthii & phyllidia in all species & detachable from the thalli & grey to golden brown \\
\hline S. pseudobeauvoisii & & & pale grey to dark brown \\
\hline S. scabrosa & & & pale grey to dark grey \\
\hline S. phyllidiata & lobules in all species & small lobes & brown to black \\
\hline S. squamifera & & & dark brown \\
\hline S. tatamana & absent & - & golden-brown \\
\hline S. andina & isidia and phyllidia & flattened & dark brown to black \\
\hline S. beauvosii & & cylindrical to flattened & brown gold \\
\hline S. carolinensis & & phyllidate & cream \\
\hline S. hypoglabra & & cylindrical & grey to brown \\
\hline S. isidiokunthii & & branched to coralloid & beige \\
\hline S. luteocyphellata & isidia in all species & simple to branched & grey to brown \\
\hline S. rhizinata & & branched to coralloid & brown to black \\
\hline S. tunjensis & & branched to coralloid & white to cream \\
\hline S. waikamoi & & cylindrical to flattened & dark brown \\
\hline S. weigelii & & coralloid & brown to black \\
\hline
\end{tabular}

* Sticta sp. undescribed species provincially called Sticta lobulata in Moncada (2012) and Moncada et al. $(2014,2020)$ is characterized by the presence of lobules. 
Taxa closely related to $S$. weigelii s.str. are S. "luteocyphellata" and S. tatamana (Fig. 1). However, in S. tatamana the tomentum is pale golden-brown and in S. "luteocyphellata" browngrey with paler apices. Additionally, in S. tatamana no vegetative propagules were observed (Moncada, 2012; Moncada et al., 2013a).

Recently, new taxa morphologically similar to S. weigelii s.str. have been described: S. waikamoi from Hawaii and S. harrisii from Puerto Rico (Mercado-Díaz et al., 2020; Moncada et al., 2020, 2021b). Sticta harrisii is characterised by the presence of phyllidia and tomentum is paler than in S. weigelii s.str. and becomes yellowish in herbarium specimens (Mercado-Diaz et al., 2020). In S. waikamoi, the marginal isidia are cylindrical to somewhat flattened (Moncada et al., 2020, 2021b). Both species are unrelated phylogenetically to $S$. weigelii s.str. (MercadoDíaz et al., 2020; Moncada et al., 2020, 2021b).

\section{THE SPECIES}

Sticta Weigeli (Ach.) Vain. (Fig. 2)

Description. Photobiont: cyanobacteria. Stipe absent. Thallus closely to loosely adnate, up to $8 \mathrm{~cm}$ wide, irregular to suborbicular, moderately branched. Lobes $7-10 \mathrm{~mm}$ wide and $2-18 \mathrm{~mm}$ long, laciniate, elongate with rounded apices, margins sinuous, not thickened, densely isidiate. Upper surface reddish-brown to dark brown with black marginal line, smooth to slightly scrobiculate, shiny, without papillae. Apothecia and cilia absent. Isidia numerous, mainly marginal, aggregated, branched-coralloid, darker than the thallus, blackish-brown. Medulla white to cream-white, $\mathrm{K}+$ intensive yellow. Lower surface beige to red-brown toward the centrum. Tomentum rather thin, dense but shorter on margins, spongy, dark brown. Rhizines often present, irregularly scattered, black, up to $2 \mathrm{~mm}$ long. Cyphellae abundant, 0.5-1 $\mathrm{mm}$ diam, with white to beige or partly yellow basal membrane, margins raised and involute, brown to black, rounded to irregular; $\mathrm{K}+$ yellow-orange.

Upper cortex 40-50 $\mu \mathrm{m}$ thick, differentiated into two cell layer; upper layer 3.5-5 $\mu \mathrm{m}$ diam, 1 cell layer; lower layer 6-12 $\mu \mathrm{m}$ diam, 4-5 cells. Photobiont layer 40-50 $\mu \mathrm{m}$ thick, cells $12-20 \mu \mathrm{m}$ diam, with orange-yellow crystals. Lower cortex 27-33 $\mu \mathrm{m}$ thick, cells $6-12 \mu \mathrm{m}$ diam with wall
1-2.5 $\mu \mathrm{m}$ thick. Tomentum 170-320 $\mu \mathrm{m}$ long, in dense fasicles. Cyphellae por 210-740 $\mu \mathrm{m}$ diam, basal membrane 240-950 $\mu \mathrm{m}$ diam (based on own observations and Moncada 2012).

Notes. The diagnostic features of $S$. weigelii s.str. are the cylindrical isidia darker than the thallus, the dark brown, rather thin lower tomentum, and the white to partly yellow cyphellae (Moncada, 2012; Moncada et al., 2021a). For differences from other similar taxa see Table 1.

Distribution and habitat. The records of $S$. weigelii s.str. presented here are the first from Bolivia supported by molecular data. So far, it was reported only by Herzog $(1922,1923)$ and Feuerer et al. (1998), but these records were not confirmed using molecular markers and may represent other species. In Bolivia the species occurs in the departments Cochabamba, La Paz, Tarija and Santa Cruz, where it grows on bark of trees and rocks, at 750-3950 m above sea level. Sticta weigelii s.str. was reported also from Colombia, Martinique (type locality), and Puerto Rico (Galloway, 2006; Moncada, 2012; Moncada et al., 2014a, 2021a; Mercado-Diaz et al. 2021). Previously, S. weigelii s.lat. was considered as a widespread species, reported from many localities in Asia, East Africa, Central and South America, Australia and several Pacific islands (Swinscow \& Krog, 1988; Galloway, 1994, 1997, 2006 and literature cited therein). However, according to Moncada et al. (2021a) records outside the Neotropical region should be considered doubtful until confirmed by phylogenetic results.

Specimens examined: BOLIVIA. Dept. Cochabamba, Prov. Chapare, Parque Nacional Carrasco, $148 \mathrm{~km}$ of the old road from Cochabamba to Villa Tunari, $17^{\circ} 07^{\prime} \mathrm{S}, 65^{\circ} 34^{\prime} \mathrm{W}$, alt. $1050 \mathrm{~m}$, fallen tree in humid forest, corticolous, 10 Oct. 1997, leg. K. Bach 657 \& M. Kessler, E. Rapp (LPB); Dept. La Paz, Prov. Nor Yungas, near Pacallo village, $16^{\circ} 12^{\prime} 10^{\prime \prime} \mathrm{S}, 67^{\circ} 50^{\prime} 39^{\prime \prime} \mathrm{W}$, alt. 1360 $\mathrm{m}$, montane forest, on stone, 03 Aug. 2008, leg. M. Kukwa 7152 (LPB, UGDA; GenBank accession no MZ292977); Dept. La Paz, Prov. Nor Yungas, near Pongo village, near the road Coroico-Laz Paz, 16 19'28”S, 67 57'21'W, alt. 3822 m, Páramo Yungueño, 26 Nov. 2011, leg. M. Kukwa 10456 (LPB, UGDA); Dept. La Paz, Prov. Sud Yungas, Alto Beni Sapecho, Colonia Tupiza, Parcela Permanente III, on Pousenia 

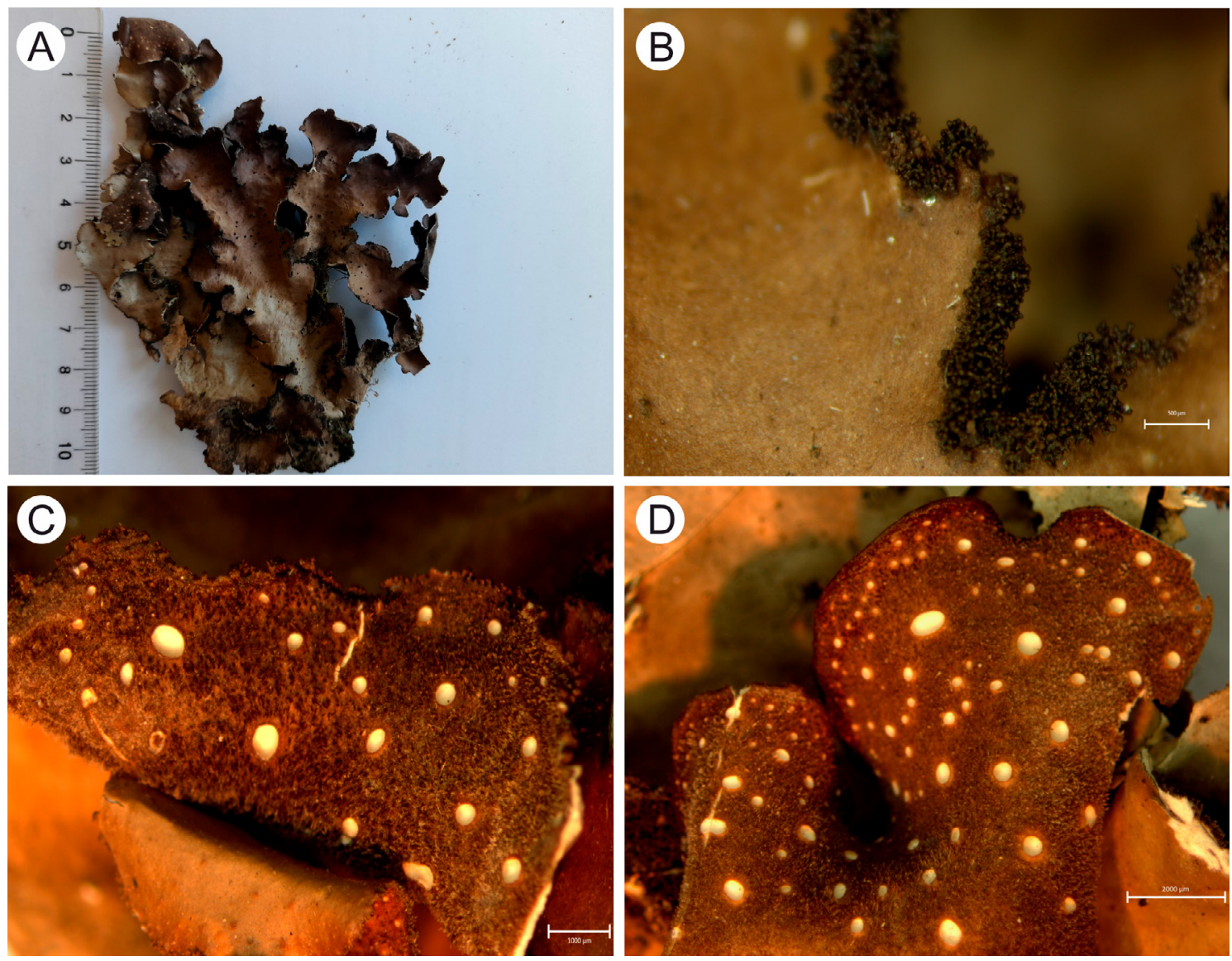

Fig. 2. Morphology of Sticta weigelii (Ach.) Vain. A - thallus; B - upper surface with dark marginal isidia; C - lower surface with black tomentum, cyphellae and marginal isidia; D - lower surface with black tomenum and cyphellae. All from Flakus 18429 (LPB, KRAM). Scale bars: $1000 \mu$ m.

armata, $15^{\circ} 31^{\prime} \mathrm{S}, 67^{\circ} 17^{\prime} \mathrm{W}$, alt. $750 \mathrm{~m}$, Evergreen to semi-deciduous forest, on branches, 02 July 1999, leg. A. Acebey (LPB); Dept. La Paz, Prov. B. Saavedra, $15 \mathrm{~km}$ from Charazani to Apollo, $15^{\circ} 11^{\prime} \mathrm{S}, 68^{\circ} 52 \mathrm{~W}$, alt. $3500 \mathrm{~m}$, humid forest, corticolous, 04 July 1997, leg. K. Bach 346 \& M. Kessler, J. Gonzales, A. Acebey, V. Rapp (LPB); Dept. La Paz, Prov. B. Saavedra, $3 \mathrm{~km}$ de Pauji-Tuyo hacia Charazani, $15^{\circ} 02^{\prime} \mathrm{S}, 68^{\circ} 29^{\prime} \mathrm{W}$, alt. $1300 \mathrm{~m}$, evergreen virgin forest, corticolous, 05 June 1997, leg. K. Bach 144 \& M. Kessler, A. Acebey, E. Rapp (LPB); Dept. La Paz, Prov. Umrillo, arriba Chururagni, alt. 1900 m, 28 Aug. 1988, leg. S. Stab 264 (LPB); Dept. Santa Cruz, Prov. Manuel Caballero, near Siberia, $17^{\circ} 49^{\prime} 38^{\prime \prime S}$, 644'45”W, alt. $3950 \mathrm{~m}$, open Yungas cloud forest, corticolous 16 Aug. 2012, leg. M. Kukwa 11422 (LPB, UGDA); Dept. Tarija, Prov. Aniceto Arce, Filo de Sidras, $22^{\circ} 14^{\prime} 50$ ”'S, 64³3'28”W, alt. $1064 \mathrm{~m}$, Tucumano-Boliviano submontane forest, corticolous 22 Nov. 2010, leg. A. Flakus 18429 (LPB, KRAM; GenBank accession no MZ292976).

\section{ACKNOWLEDGEMENTS}

I am are greatly indebted to Adam Flakus and Pamela Rodriguez de Flakus (Kraków, Poland) for sending material for the study, Martin Kukwa (Gdańsk, Poland) and Robert Lücking (Berlin, Germany) for helpful comments and reviewing the first version of this manuscript, Beata Guzow-Krzemińska, Magdalena Kosecka and Sandra Olszewska (Gdańsk, Poland) for 
help with phylogenetic analyses. I am also very grateful to the members of Herbario Nacional de Bolivia, Instituto de Ecología, Universidad Mayor de San Andrés, La Paz, for the generous cooperation. The research was supported by the University of Gdansk.

\section{REFERENCES}

Altschul, S. F., Madden, T. L., Schäffer, A. A., Zhang, J., Zhang, Z., Miller, W. \& Lipman, J. 1997. Gapped BLAST and PSI-BLAST: a new generation of protein database search programs. $\mathrm{Nu}$ cleic Acids Research 25: 3389-3402. https:/ / doi. org/10.1093/nar/25.17.3389

Edgar, R. C. 2004. MUSCLE: multiple sequence alignment with high accuracy and high throughput. Nucleic Acids Research 32: 1792-1797. https:// doi.org/10.1093/nar/gkh340

Feuerer, T., Ahti, T. \& Vitikainen, O. 1998. Lichenological investigations in Bolivia. In: Marcelli, M. P. \& Seaward, M. R. D. (eds) Lichenology in Latin America: History, current knowledge and applications, pp. 71-86.

Galloway, D. J. 1994. Studies on the lichen genus Sticta (Schreber) Ach.: I. Southern South American species. Lichenologist 26: 223-282.

Galloway, D. J. 1997. Studies on the lichen genus Sticta (Schreber) Ach. IV. New Zealand species. Lichenologist 29: 105-168.

Galloway, D. J. 2006. Notes on the holotype of Sticta damaecornis $\beta$ weigelii Ach. (= Sticta weigelii). Lichenologist 38: 89-92. https://doi.org/10.1017/ S0024282905015598

Galloway, D. J. 2007. Flora of New Zealand Lichens. Revised Second Edition Including Lichen-Forming and Lichenicolous Fungi. Volume 2. Manaaki Whenua Press, Lincoln, New Zealand. 2397 pp.

Galtier, N., Gouy, M. \& Gautier, C. 1996. SeaView and Phylo_win: two graphic tools for sequence alignment and molecular phylogeny. Computer applications in the biosciences 12: 543-548. https:/ / doi. org/10.1093/bioinformatics / 12.6.543

Gardes, M. \& Bruns, T. D. 1993. ITS primers with enhanced specificity for basidiomycetes-application to the identification of mycorrhizae and rust. Molecular Ecology 2: 113-118. https:/ / doi. org/10.1111/j.1365-294X.1993.tb00005.x

Gouy, M., Guindon, S. \& Gascuel, O. 2010. SeaView version 4: a multiplatform graphical user interface for sequence alignment and phylogenetic tree building. Molecular Biology and Evolution 27: 221-224. https://doi.org/10.1093/molbev/ msp259

Guzow-Krzemińska, B., Flakus, A., Kosecka, M., Jabłońska, A., Rodriguez-Flakus P. \& Kukwa. M. 2019. New species and records of lichens from Bolivia. Phytotaxa 397: 257-279. https://doi. org/10.11646/phytotaxa.397.4.1
Herzog, T. 1922. Beitrag zur Flechtenflora von Bolivia. Hedwigia 63: 263-268.

Herzog, T. 1923. Die Pflanzenwelt der bolivianischen Anden und ihres östlichen Vorlandes. In: Engler, A. \& Drude, O. (eds) Die Vegetation der Erde, volume XV. Leipzig. 258 pp.

Huelsenbeck, J. P. \& Ronquist, F. 2001. MRBAYES: Bayesian inference of phylogenetic trees. Bioinformatics 17: 754-755. https://doi.org/10.1093/ bioinformatics / 17.8.754

Lücking, R., Moncada, B. \& Smith, C. W. 2017. The genus Lobariella (Ascomycota: Lobariaceae) in Hawaii: late colonization, high inferred endemism, and three new species. Lichenologist 49: 673-691. https://doi.org/ 10.1017/S0024282917000470

Lücking, R., Moncada, B., Soto-Medina, E., Simijaca, D. \& Sipman, H. J. M. 2021. Actualización nomenclatural y taxonómica del Catálogo de Liquenes de Colombia. Revista de la Academia Colombiana de Ciencias Exactas Físicas y Naturales 18: 1-43. https://doi.org/10.18257/raccefyn. 1266

McDonald, T., Miadlikowska, J. \& Lutzoni, F. 2003. The lichen genus Sticta in the Great Smoky Mountains: A phylogenetic study of morphological, chemical, and molecular data. The Bryologist 106(1): 61-79. https://doi.org/10.1639/0007-2 745(2003) 106[0061:TLGSIT]2.0.CO;2

Mercado-Díaz, J. A., Lücking, R., Moncada, B., Widhelm, T. J. \& Lumbsch, H. T. 2020. Elucidating species richness in lichen fungi: The genus Sticta (Ascomycota: Peltigeraceae) in Puerto Rico. Taxon 69 (5): 851-891. https:/ /doi.org/10.1002/ tax. 12320

Miller, M. A., Pfeiffer, W. \& Schwartz, T. 2010. Creating the CIPRES Science Gateway for Inference of Large Phylogenetic Trees. Proceedings of the Gateway Computing Environments Workshop (GCE), 14 November, 2010, New Orleans, 8 pp. https://doi.org/10.1109/GCE.2010.5676129

Moncada, B. 2012. El género Sticta (Schreb.) Ach. en Colombia, Taxonomía, Ecogeografia e Importancia. Doctoral thesis, Universidad Nacional de Colombia, Bogotá. 418 pp.

Moncada, B. \& Lücking, R. 2012. Ten new species of Sticta and counting: Colombia as a hot spot for unrecognized diversification in a conspicuous macrolichen genus. Phytotaxa 74: 1-29. https:// doi.org/10.11646/phytotaxa.74.1.1

Moncada, B., Coca, L. F.\& Lücking, R. 2013a. Neotropical members of Sticta (lichenized Ascomycota: Lobariaceae) forming photosymbiodemes, with the description of seven new species. The Bryologist 116(2): 169-200. https://doi.org/10.1639/00072745-116.2.169

Moncada, B., Lücking, R. \& Coca, L. F. 2013b. Six new apotheciate species of Sticta (lichenized Ascomycota: Lobariaceae) from the Colombian Andes. Lichenologist 45(5): 635-656. https:/ / doi. org/10.1017/S0024282913000376 
Moncada, B., Aguirre, J. \& Lücking. R. 2014 a. Ecogeografía del género Sticta. (Ascomycota liquenizados: Lobariaceae) en Colombia. Revista de Biologia Tropical 62(1): 257-272. https://doi. org/10.15517/rbt.v62i1.3564

Moncada, B., Lücking, R. \& Suárez, A. 2014b. Molecular phylogeny of the genus Sticta (lichenized Ascomycota: Lobariaceae) in Colombia. Fungal Diversity 64: 205-231. https://doi.org/10.1007/ s13225-013-0230-0

Moncada, B., Mercado-Díaz, J. A. \& Lücking, R. 2018. The identity of Sticta damicornis (Ascomycota: Lobariaceae): a presumably widespread taxon is a Caribbean endemic. Lichenologist 50 (5): 591-597. https://doi.org/10.1017/S0024282918000373

Moncada, B., Lücking, R. \& Lumbsch, H. T. 2020. Rewriting the evolutionary history of the lichen genus Sticta (Ascomycota: Peltigeraceae subfam. Lobarioideae) in the Hawaiian islands. Plant and Fungal Systematics 65(1): 95-119. https://doi. org/10.35535/pfsyst-2020-0005

Moncada, B., Mercado-Díaz, J. A., Smith, C. W., Bungartz, F., Sérusiaux, E., Lumbsch, H. T. \& Lücking, R. 2021a. Two new common, previously unrecognized species in the Sticta weigelii morphodeme (Ascomycota: Peltigeraceae). Willdenowia 51: 35-45. https://doi.org/10.3372/wi.51.51103

Moncada, B., Smith, C. W. \& Lücking, R. 2021 b. A taxonomic reassessment of the genus Sticta (lichenized Ascomycota: Peltigeraceae) in the Hawaiian archipelago. Lichenologist 53: 117-133. https://doi.org/10.1017/S0024282920000353

Nylander, W. 1859. Lichenes in regionibus exoticis quibusdam vigentes exponit synopticis enumerationibus. Annales des Sciences Naturelles, la botanique 11: 205-264.

Nylander, W. 1861. Additamentum ad lichenographiam Andium Boliviensium. Annales des Sciences Naturelles, la botanique 15: 365-382.

Nylander, J. A. A. 2004. MrModeltest v2. Program distributed by the author. Evolutionary Biology Centre, Uppsala University, Uppsala.

Orange, A., James, P. W. \& White, F. J. 2001. Microchemical methods for the identification of lichens. British Lichen Society, London. 101 pp.
Rodriguez de Flakus, P., Kukwa, M., Etayo, J., Lücking, R., Meneses, R. I., Rivas Plata, E., Stanton, D., Truong, C., Vargas, R. \& Flakus, A. 2016. Preliminary catalogue of lichens and lichenicolous fungi from Bolivia. Version 1.5. 31 December 2016. http://bio.botany.pl/lichens-bolivia/ en,strona,catalogue, 5.html [Accessed 31.03.2021]

Ronquist, H. \& Huelsenbeck, J. P. 2003. MrBayes 3: Bayesian phylogenetic inference under mixed models. Bioinformatics 19: 1572-1574. https:// doi.org/10.1093/bioinformatics/btg180

Rusby, H. H. 1896. An enumeration of the plant collected in Bolivia by Miguel Bang, with description of new genera and species. Part III. Memories of the Torrey Botanical Club 6(1): 1-130.

Simon, A., Goffinet, B., Magain, N. \& Sérusiaux, E. 2018. High diversity, high insular endemism and recent origin in the lichen genus Sticta (lichenized Ascomycota, Peltigerales) in Madagascar and the Mascarenes. Molecular Phylogenetics and Evolution 122: 15-28. https://doi.org/10.1016/j. ympev.2018.01.012

Swinscow, T. D. V. \& Krog, H. 1988. Macrolichens of East Africa. British Museum (Natural History), London. 390 pp.

Suárez, A. \& Lücking, R. 2013. Sticta viviana (lichenized Ascomycota: Peltigerales: Lobariaceae), a new species from Colombian paramos. Lichenologist 45(2): 153-157. https://doi.org/10.1017/ S0024282912000680

White, T. J, Bruns, T., Lee, S. \& Taylor, J. 1990. Amplification and direct sequencing of fungal ribosomal RNA genes for phylogenetics. In: Innis, M. A., Gelfand, D. H., Sninsky, J. J. \& White, T. J. (eds) PCR Protocols: a Guide to Methods and Applications Academic Press. New York, pp. 315-322. https:// doi.org/10.1016/B978-0-12-372180-8.50042-1

Widhelm, T. J., Bertoletti, F. R., Asztalos, M. J., Mercado-Diaz, J. A., Huanga, J.-P., Moncada, B., Lücking, R., Magain, N., Sérusiaux, E., Goffinet, B., Crouch, N., Mason-Gamerb, R. \&. Lumbsch H. T. 2018. Oligocene origin and drivers of diversification in the genus Sticta (Lobariaceae, Ascomycota). Molecular Phylogenetics and Evolution 126: 58-73. https://doi.org/10.1016/j. ympev.2018.04.006 